\title{
Petit-spot with Maar like edifice
}

Teruaki Ishii ${ }^{1}$, Makoto Kaneko ${ }^{2}$, Naoto Hirano $^{3}$, Shiki Machida $^{4}$, Yuki Sato ${ }^{3}$

${ }^{1}$ Center for IRE of Natural Hazards, Sizuoka University, ishiiteruaki@hotmail.com, ${ }^{2}$ Fukada Geological Institute, ${ }^{3}$ Tohoku University, ${ }^{4}$ Chiba Institute of Technology.

The Pacific Plate is subducting at the Japan Trench off NE Japan. Just immediately before the subduction, the new type volcanoes with young age and small edifice were found on the ocean floor, off Tohoku and named as petit-spot ${ }^{1}$.

According to Hirano and Machida's group studies ${ }^{1,2,3,4}$, petitspot volcanoes are divided into two types ; I type petit-spot

( = IPS ) and D type petit-spot (= DPS ) which are indirectly ascending petit-spots and directly ascending petitspots of asthenospheric magma, respectively. The former and the later are locating concave regions and convex (=outer rise) regions of the plate, respectively. IPS; At the concave regions of the Pacific Plate, lower part of the plate may be opened and upper part of plate may have stress, so the magmas originate from the asthenosphere immediately below the plate, may assent through the lower part of the plate and stop at middle of the plate and make secondary magma reservoir, where magmas may be petrologically modified and made secondary magmas. IPS may be induced by the modified magma's eruption ${ }^{2}$.

DPS; At the convex region of the plate, generally speaking lower part of the plate may be under stress, if so the magmas below the plate cannot assent. According to the stress field change of the lithosphere, direct ascent to the surface of magma induced in a region of convex lithospheric flexure at off Fukushima. DPS may be induced by the direct ascent magma's eruption ${ }^{3}$.

We found DPS with Maar like edifice about $5500 \mathrm{~m}$ deep, at the convex region ${ }^{4}$. The edifice has the following characters; the crater rim is about $5700 \mathrm{~m}$ deep and its diameter is about $600 \mathrm{~m}$. The crater bottom is about $5730 \mathrm{~m}$ deep and flat. It is topographically very similar to the Ichino-megata volcano, in Yamagata, Japan, which is known as typical Maar in Japan. Dredged samples are glassy vesicular basalts, mudstone, ferromanganese rock, pumice, a few rounded rocks (dolerite and sandstone) and soft sediment (mud) with basaltic fragment. Basalts is glassy, aphyric and very vesicular, and some basalt lava have quenched glass rind. We need more detailed observation on geology and petrography of the volcano, such methods using Shinkai 6500 dive. The volcano may be best target of IODP scientific drilling.

Refernces: ${ }^{1}$ Hirano et al. (2006) Science 313, 1426-1428.

${ }^{2}$ Machida et al. (2015) EPSL 426, 267-279. ${ }^{3}$ Sato et al. (2018) Int'l Geol. Rev., 60, 1231-1243. ${ }^{4}$ Ishii et al. (2019) Annual Rep., Fukada Geol.Inst., 20, 105-128 (in Japanese). 